\title{
The OSCE Institutional and Operational Possibilities in the Modern Conflict Resolution
}

\section{By Example of the Activity of the osce Special Monitoring Mission to Ukraine}

\author{
Lesia Dorosh \\ Associate Professor, Department of Political Science and International \\ Relations, Lviv Polytechnic National University, Lviv, Ukraine \\ lesia.o.dorosh@lpnu.ua \\ Olga Ivasechko \\ Associate Professor, Department of Political Science and International \\ Relations, Lviv Polytechnic National University, Lviv, Ukraine \\ ivasechko.2011@ukr.net
}

\begin{abstract}
The strengths and weaknesses of the osce Special Monitoring Mission (SMm) to Ukraine are analyzed including the effectiveness of the organization's activities in resolving modern international conflicts, as well as its opportunities and challenges in this process. The OSCE SMM activities in Ukraine are investigated, mainly its institutional and procedural dimensions. Emphasis is placed on the idea that the OSCE is the main and only international governmental institution that promptly responds to the emergence of conflicts, uses already developed methods for their solution, and provides all members with information on compliance with the agreement by the parties.
\end{abstract}

\section{Keywords}

OSCE - osCE Special Monitoring Mission - Ukraine conflict - conflict resolution international security 
The international security system, its European segment, in particular, is now facing numerous challenges, including hybrid ones. Challenges relate to an increase in the level of the military ( $h a r d$ ) and non-military (soft) threats (terrorism, illegal migration, illegal arms trade, illegal drug trafficking, etc.). One should not forget about active and frozen armed conflicts in Europe (for instance, the Russian military intervention in Georgia and Eastern Ukraine). Those and other challenges cause the transformation of the established security system, its institutional and procedural dimensions; these challenges predetermine the need for defining the factors that will provide its efficiency in such dimensions.

Nowadays the Organisation for Security and Co-operation in Europe (OSCE) is an element of the institutional dimension of the European security system. The OSCE is the largest specialized regional security organisation on Earth involved in resolving many conflicts. The OSCE contributes to peace and maintains stability in the post-Soviet space, including Ukraine. In April 2014, Thomas Greminger called the Ukraine crisis 'a curse and an opportunity' for this organisation. In five years, according to experts, the statement remains relevant. ${ }^{1}$ It should be mentioned that the OSCE is a multilateral, intergovernmental organisation where its effectiveness depends almost entirely on the political will and support of its participating States. The OSCE has no coercive power or legal obligation to its members. This, in turn, requires the organisation to search for methods of implementing its decisions based on conviction instead of coercion. ${ }^{2}$

There seems to be no compelling reason to argue that Ukrainian security is considered an inalienable component of European security, in particular, in the light of Russian intervention in Ukraine. Signing various political and legal acts on security by Ukraine as well as Ukraine's membership in international security organisations, based on the observance of democratic principles of solidarity and mutual support of nations, should have given it real security guarantees. However, as the conflict of Ukraine and Moscow proxies enters its fifth year, the violations of the Minsk Agreements regarding the Donbas region continue, and Ukrainian soldiers are killed every day. This forms an assumption from Ukrainian experts and the public that the lack of reliable guarantees

1 Christian Nünlist, 'Reviving Dialogue and Trust in the OSCE in 2018', in Center for Security Studies (css), 2017a. Available at https://css.ethz.ch/en/services/digital-library/articles/article.html/5dıbd2ac-1928-4942-93e6-cdocdo44662f/pdf, 15 Jan 2018 (accessed 22 June 2019).

2 Cohen J., 'Conflict Prevention in the oscE', The Hague, Netherlands Institute of International relations Clingendael, 1999, p. 11. 
of international security puts Ukraine into a situation of a security 'vacuum, ${ }^{3}$ and the activity of international organisations proves their inability to put an end to violence. Thus, despite the OSCE's activities in regulating and preventing conflicts in Europe, many experts put forward the view about organisation's low effective actions in the security area and/or inability of international legal mechanisms to ensure security in modern terms in general. Considering this, while searching for mechanisms and means to solve the conflict in Eastern Ukraine, with the participation of the OSCE, the present study scrutinizes the efficiency level of OSCE activity and the search for optimal methods for the organisation to establish democracy and peace in Europe. Through the utilisation of the Strength-Weakness-Opportunities-Threat (swot) analysis, the present study provides confirmatory evidence of the peculiarities of the OSCE mission in Ukraine in institutional and operational dimensions.

The conflict in Eastern Ukraine has not been solved yet. The fundamental principles of international relations such as respect for the States' territorial integrity, inviolability of borders, and refraining from the threat or use of force continue to be violated. In view of the fact that the OSCE Special Monitoring Mission (SMM) is involved in Russian-Ukrainian conflict resolution, its activity is often criticised. Some researchers claim that the SM M's success or failure will impact not only the situation in Ukraine but also the OSCE's entire future and its capability to operate in conflict regions. ${ }^{4}$ Therefore, this study is an attempt to comprehensively address the issue of the OSCE's role in resolving the conflict. This is concerned with the issue of the legal framework, the work of its institutions and the operational activities in the field. The point is that taking into consideration such various criteria as the developing of a peaceful settlement program, the response of OSCE bodies to crises and operational activity of the special missions will help us to find the gaps existing in the organisation structure and functioning, and to determine the capabilities of the international organisation in resolving existing and preventing international conflicts. Consequently, the SWOT-analysis of the activities of the OSCE mission to Ukraine is relevant and will allow finding shortcomings in the OSCE work, emphasising the organisation's success and developing recommendations on resolving such conflicts in the future.

3 Borys Parakhonskyi and Halyna Yavorska, 'Rol oвsıe u formuvanni yevropeiskoho seredovyshcha bezpeky', in Stratehichni priorytety, 2013, 3 (28), pp. 109-114, Available at http:// nbuv.gov.ua/j-pdf/spa_2013_3_16.pdf (accessed 2 August 2019).

4 Dennis Sammut and Joseph D'Urso, 'The Special Monitoring Mission in Ukraine: a useful but flawed OsCE tool', in European Policy Centre, POLICY BRIEF, 2015. Available at https://www.files .ethz.ch/isn/190397/pub_5511_the_special_monitoring_mission_in_ukraine.pdf (accessed 22 June 2019). 
The article aims to identify the strengths and weaknesses of the OSCE mission to Ukraine and to analyse the extent of the effectiveness of the organisation's activities in resolving modern international conflicts, as well as its opportunities and challenges in this process.

\section{The Theoretical Basis of the Study}

The theoretical framework of the research includes research papers devoted to defining the kinds of threats that are prevailing in the modern security space. The centrality is given to the issues of providing 'soft security', countering the potential and actual political, social and economic challenges of national security. ${ }^{5}$ The only exception is the defence issues of 'hard' types of security. ${ }^{6}$ The consensus view seems to be that today's tendency is the transformation of the local and regional security threats into the global ones.

W. Weidenfeld, W. Wessels, D. Kaniewski, C. Wendling, K. Becher, and F. Moustakis ${ }^{7}$ are prominent in the literature on the conditions for the existence, tasks and main goals of the OSCE as well as the OSCE's impact on the formation of the European security system. The approaches of these scholars to the assessment of modern processes in European security as well as their understanding of the optimality of the OSCE's structure and functioning efficiency are differentiated.

Research papers on the ability of the OSCE to regulate the crisis within the context of peacekeeping and conflict resolution in the world, as well as the

5 Fotios Moustakis, 'Soft Security Threats in the New Europe', in C. George Marshal European Centre for Security Studies, Managing the Challenges of Soft Security Threats in the 21st Century «Report of the Conference», 2004, p. 6.

6 Cécile Wendling, The Comprehensive Approach to Civil-Military Crisis Management: A Critical Analysis and Perspective, 2010. Available at https://www.eisf.eu/wp-content/uploads/2014/ og/0155-Wendling-2010-Comprehensive-approach.pdf (accessed 22 June 2019).

7 V. Vaidenfeld, V. Vessels (red.), Yevropa vid A do Ia. Dovidnyk z yevropeiskoi intehratsii, Lviv, 2007; K.Becher, 'Sof security' with Russia after 11 September', in The International Institute for Strategic Studies, 2005. Available at http://www.iiss.org/publications/russiaregional-perspectives-journal/volume-1-issue-1/soft-securitywith-russia-after-11-september (accessed 10 June 2019); Dmytro Kaniewski, 'The Morel Plan: Will Kyiv swallow the bitter pill?', in Deutsche Welle, 2015. Available at http://www.dw.com/en/the-morel-plan-will-kyiv-swallow-the-bitterpill/a-18756951 (accessed 22 June 2019); Fotios Moustakis, 'Soft Security Threats in the New Europe', in C. George Marshal European Centre for Security Studies, Managing the Challenges of Soft Security Threats in the 21st Century «Report of the Conference», 2004; Cécile Wendling, The Comprehensive Approach to Civil-Military Crisis Management: A Critical Analysis and Perspective, 2010. Available at https://www.eisf.eu/wp-content/uploads/2014/og/o155-Wendling2010-Comprehensive-approach.pdf (accessed 22 June 2019). 
organisation's co-operation with other international institutions to enhance the efficiency of its actions, ${ }^{8}$ should be allocated separately. J. Alsyte is prominent in the literature on both achievements and shortcomings of the OSCE by examples of different regions, including post-Soviet space, and critic of the organisation for the insufficiency of its legal power and lack of its coercive mechanisms. $^{9}$

Analytical materials that clarify the work of the OSCE in resolving conflicts in Ukraine were used for research. So, the issues of the Ukrainian conflict resolving and the functioning of the organisation's missions in Ukraine were being dealt with by D. Sammut and J. Durso ${ }^{10}$ who paid a lot of attention to the analysis of the efficiency extent of the mission to Donbas and the future of the OSCE as an organisation focused on maintaining stability in the region." Another researcher, A. Bloed, analyses the OsCE's activity in Ukraine, emphasising the uniqueness of its mission's role in resolving the conflict. ${ }^{12}$ The problems of the OSCE's work during the conflict resolution in Georgia, which are important in improving the mechanisms for resolving the Ukrainian conflict, are considered in the studies of T. Potier, ${ }^{13}$ M.-J. Rie, ${ }^{14}$ and S. Stöber. ${ }^{15}$ All these authors note the significant Russian influence on the ongoing conflict in Donbas and its destabilising role in the post-Soviet region, which hinders the OSCE's missions to effectively manage conflicts.

In addition, the specifics of the legal regulation of conflict resolution by the OSCE have been explained based on the organisation's documents signed by

8 Ed.Moxon-Browne, A future for peacekeeping?, usA: St. Martin`s Press, 1998.

9 Justina Alsyte, 'OSCE's achievements vs. Shortcomings in the resolution of armed conflicts', in Lithuanian Foreign Policy Review, 2015. Available at: http://lfpr.lt/wp-content/ uploads/2015/08/LFPR-24-Alsyte.pdf (accessed 10 June 2019).

10 Dennis Sammut and Joseph D'Urso, 'The Special Monitoring Mission in Ukraine: a useful but flawed osCE tool', in European Policy Centre, POLICY BRIEF, 2015. Available at https:// www.files.ethz.ch/isn/190397/pub_5511_the_special_monitoring_mission_in_ukraine.pdf (accessed 22 June 2019).

11 Silvia Stöber, 'The Failure of the osce Mission to Georgia - What Remains?', in IFsH (ed.), OSCE Yearbook 2010, Baden-Baden, 2011, pp. 203-220. Available at https://ifsh.de/fileCORE/documents/yearbook/english/10/Stoeber-en.pdf (accessed 22 June 2019).

12 A.Bloed, 'Osce Revitalized by Ukraine Crisis', in Security and Human Rights, 2014. No.25, p. 9 .

13 T.Potier, Conflict in Nagorno-Karabakh, Abkhazia and South Ossetia, Hague: Kluwer Law International, 2001.

14 M.-J.Rie, 'The role of the OSCE in the conflict in Georgia', in Security and Human Rights, 2009, no.4, pp. 318-324.

15 Silvia Stöber, 'The Failure of the osce Mission to Georgia - What Remains?', in IFSH (ed.), OSCE Yearbook 2010, Baden-Baden, 2011, pp. 203-220. Available at https://ifsh.de/fileCORE/documents/yearbook/english/10/Stoeber-en.pdf (accessed 22 June 2019). 
its Member States. In particular, the 'Protocol on the results of consultations of the Trilateral Contact Group with respect to the joint steps aimed at the implementation of the Peace Plan of the President of Ukraine, P. Poroshenko, and the initiatives of the President of Russia, V. Putin'16 were reviewed, along with the Package of Measures for the Implementation of the Minsk Agreements. ${ }^{17}$ Both documents have become the result of the complex multilateral and multilevel discussions, and they contain the instructions that are necessary to end the military phase of the conflict in Donbas. The SMM monitors the implementation of the Minsk Agreements and objectively reports on the situation in the East of Ukraine, as well as facilitates a dialogue between the parties to the conflict. In Ukraine, the OSCE is the only international organisation that monitors the situation in the conflict area. Moreover, the SM M conducts regular meetings with civilians and organises round tables with the authorities and citizens. The mission ensures the delivery of humanitarian aid, as well as the access of repair teams to places along the front line. After the accident with the Malaysia Airplane in the Donetsk region, SMM was the first international observer to arrive at the scene. They also provided international experts access to the accident. ${ }^{18}$

The Paris Summit in the Normandy Format, including the President of the French Republic, the Chancellor of the Federal Republic of Germany, the President of the Russian Federation, and the President of Ukraine was held on 9 December 2019 in Paris. During the Summit, leaders reconfirmed that the SMM should be able to use all the capabilities of the mandate (as of March 21, 2014) and have safe and secure access throughout Ukraine for the full implementation of its mandate. ${ }^{19}$ Ukrainian president, Volodymyr Zelenskyy, stressed that it had been agreed during Normandy format meeting to extend the mandate

16 'Protokol po itogam konsul'tacij Trehstoronnej kontaktnoj gruppy otnositel'no sovmestnyh shagov, napravlennyh na implementaciju Mirnogo plana Prezidenta Ukrainy P. Poroshenko i iniciativ Prezidenta Rossii V. Putina', osCE:Organization for Security and Co-operation in Europe, 2014. Available at http://www.osce.org/ru/home/123258?download=true (accessed 22 June 2019).

17 'Kompleks mer po vypolneniju Minskih soglashenij', oscE: Organization for Security and Co-operation in Europe, 2014. Available at http://www.osce.org/ru/cio/140221?download= true (accessed 22 June 2019).

18 'Reaktsiia овsie na kryzu v Ukraini i navkolo nei', OSCE: Organization for Security and Cooperation in Europe, Available at http://www.osce.org/uk/home/125576?download=true (accessed 8 December 2019).

19 'Overall agreed conclusions of the Paris Summit in the Normandy format of December 9', 2019, President of Ukraine, 2019, Available at https://www.president.gov.ua/en/news/zagalni-uzgodzheni-visnovki-parizkogo-samitu-v-normandskomu-58797 (accessed 13 December 2019). 
of the osce Special Monitoring Mission with the possibility of conducting round-the-clock monitoring. ${ }^{20}$

The analysis of the research of the theoretical foundation and condition of the OSCE's activity in resolving the Ukrainian conflict can allow us to assume that, despite numerous present studies on the organisation's conflict resolution and its internal work, there is almost no research where the OSCE's activity on resolving conflict in Donbas is thoroughly analyz=sed and its activity in resolving other conflicts is compared. By exploring this, the authors also continue their previous research. ${ }^{21}$

There has been a conclusive debate about the peculiarities of the functioning of the OSCE as a regional organisation, the mechanisms of conflict management, the principles of work and place of the organisation in the regional system, and the efficiency of its mission's activity. These and other problems have become a subject of interest of many researchers from Western Europe, Ukraine, the USA, Russia, Canada, and other countries. There is a rapidly growing literature on the activity of the OSCE mission to Ukraine, which indicates its role in resolving the conflict in Donbas providing a comprehensive and objective assessment to peaceful regulation and negotiation methods the organisation uses in its work. Further research in this area may include prospects of the OSCE's activity and formation of the exact recommendations and suggestions for improving the OsCE's activity in resolving the Ukrainian crisis and similar conflicts.

\section{The osce Contribution to the Conflict Resolution in Ukraine}

The unique role of the OSCE in the architecture of Euro-Atlantic and Eurasian security, according to the researchers, is conditioned by the following key factors. Firstly, its "inclusivity" - the organisation geographically covers most of the northern hemisphere (from Vancouver to Vladivostok). Secondly, the

\footnotetext{
20 'Volodymyr Zelenskyy: Complete, comprehensive and unconditional ceasefire in eastern Ukraine should begin by the end of 2019', President of Ukraine, 2019, Available at https:// www.president.gov.ua/en/news/povne-vsebichne-ta-bezstrokove-pripinennya-vognyuna-shodi-u-58801 (accessed 13 December 2019).

21 L.Dorosh and R.Shchukina, 'Commonalities and differences in the functioning of the osCE special missions in Ukraine and Georgia: institutional and procedural dimensions', in Visnyk Mariupolskoho derzhavnoho universytetu. Seriia: Istoriia. Politolohiia, 2017, No. 19, pp. 125133; O.Ivasechko and M. Zdorovega, "The Matrix of the swot-analysis to the osCE functioning in the contex of the conflict in the East of Ukraine', in Visnyk Mariupolskoho derzhavnoho universytetu. Seriia: Istoriia. Politolohiia, 2017, no. 18, pp. 240-248.
} 
inclusivity of its mandate in the security spheres enabling the OSCE to consider a wide range of internal bilateral and multilateral conflicts. Thirdly, the consensus approach for decision-making within the organisation and the cooperative style of its policy. However, the principle of absolute consensus may not be possible in a case, when a party to a conflict places its hostile interests above others, ignoring interests of the whole international community, as well as its principles and commitments. It is important to introduce a coercive mechanism, whether economic or political, which could affect the parties to the conflict. Fourthly, a common legal and regulatory framework is based on two documents: the 'Decalogue' of the Helsinki Final Act and the Charter of Paris for a New Europe. The researchers also emphasise the organisation's important role in expanding, differentiating and approving its pan-European paradigm of values describing the current public order which defends human rights, national minorities, democracy, the rule of law, and a market economy. ${ }^{22}$

The OSCE has considerable experience in the post-Soviet conflict regulation. In general, several mechanisms are used to ensure a short-term search for the methods to reduce violence within the OSCE: (1) involving senior officials in the negotiations between leaders, (2) mediation, and (3) building trust, including military or civilian monitoring missions. In recent years, governments and international organisations have been significantly investing in mediation, setting up special units to assist high-level representatives. ${ }^{23}$

So, when the Russian-Ukrainian conflict began in 2014 and within it, the socalled 'people's republics' of Donetsk and Luhansk appeared, certain developments in organisation were needed in order to resolve the crisis, which began with a change in political course of the countries accompanied by the intervention of external forces (Russia) and lasting for more than four years. Defining the OSCE's peculiarities in conflict resolution in Ukraine, it is expedient to analyse the legal documents, institutional and organisational framework and operational activities of the OSCE SMM to Ukraine.

Regulatory documents, which are governed by the OSCE in dealing with the crisis, are the agreements developed by its members with the support of the organisation. The negotiations took place in different formats: Minsk - with the participation of the parties to the conflict (representatives of Ukraine, Russia, the OSCE, unrecognised self-proclaimed Luhansk People's Republic (LPR)

22 V. Vaidenfeld, V. Vessels (red.), Yevropa vid A do Ia. Dovidnyk z yevropeiskoi intehratsii, Lviv, 2007, p. 7 .

23 'Seizing the Moment: From Early Warning to Early Action', in Special Report No.2, International Crisis Group, 2016. Available at https://www.crisisgroup.org/global/seizing-moment -early-warning-early-action, 23 JUNE 2016 (accessed 22 June 2019). 
and Donetsk People's Republic (DPR)); Geneva - with the participation of Ukraine, the EU, the USA, Russia; Normandy - with the participation of the leaders of Ukraine, Germany, France, and Russia.

The first agreement between the parties to the conflict (Minsk Protocol) on a temporary armistice was reached on September 1, 2014, after the escalation of the conflict in Eastern Ukraine. The osCE Representative Ambassador Heidi Tagliavini, Second President of Ukraine L.Kuchma, Ambassador of Russian Federation to Ukraine M. Zurabov participated in the document's preparation and signing. The representatives of the self-proclaimed republics A. Zakharchenko and I. Plotnitskii also signed the document. This Protocol anticipated ceasefire; decentralization of power in Ukraine and adoption of the Law on the Special Status of Donetsk and Luhansk regions; holding snap local elections in these regions; the withdrawal of illegal armed groups, military equipment, soldiers and mercenaries from the territory of Ukraine, etc. The OSCE was responsible for monitoring compliance with the terms of the Agreement, including monitoring of the ceasefire regime in the conflict zone and the situation at the Ukrainian-Russian state border. ${ }^{24}$ However, many clauses were not fulfilled by the parties to the conflict; instead, the OSCE was constantly recording cases of violation of the silence regime at the line of demarcation. Additionally, the snap elections on the territories were not held because of the continuing presence of illegal armed groups.

A Normandy Format Summit was held by the leaders of Germany, France, Ukraine, and Russia due to the previous unfulfilled multilateral agreements and the escalation of the conflict in 2015. The participants developed the Package of Measures for the Implementation of the Minsk Agreements (Minsk II), which included specific conditions on disarmament, hostage release and holding elections. According to them, the OSCE mission to Ukraine had to monitor the removal of heavy weapons by the parties to the line of demarcation, and the osce Office for Democratic Institutions and Human Rights was to monitor the holding of democratic elections in the Ukrainian territories of Donetsk and Luhansk regions controlled by the Russian Federation. ${ }^{25}$ However, while the agreement was being partially implemented, it did not solve the

24 'Protokol po itogam konsul'tacij Trehstoronnej kontaktnoj gruppy otnositel'no sovmestnyh shagov, napravlennyh na implementaciju Mirnogo plana Prezidenta Ukrainy P. Poroshenko i iniciativ Prezidenta Rossii V. Putina', osce: Organization for Security and Cooperation in Europe, 2014. Available at http://www.osce.org/ru/home/123258?download $=$ true (accessed 22 June 2019).

25 'Kompleks mer po vypolneniju Minskih soglashenij', oscE: Organization for Security and Co-operation in Europe, 2014. Available at http://www.osce.org/ru/cio/140221?download =true (accessed 22 June 2019). 
problem of control of Kyiv over the part of the Ukrainian-Russian border in the Donetsk and Luhansk regions. Immediately after the Agreement was signed, the OSCE Special Monitoring Mission recorded ceasefire violations in Lugansk, Donetsk, Debaltseve, and Raygorodka. ${ }^{26}$ According to smm reports, these violations continue every day. After all, researchers argue that in Eastern Ukraine, 'the Minsk process [risks] becoming a substitute for a settlement', as Russia follows a deliberate strategy of making 'parties concentrate more on the process than the settlement'. ${ }^{27}$ In addition, many accuse the previous Ukrainian administration of not being interested in the actual conflict settlement and dragging out the process. Thus, as The Economist points out:

...there is a problem that too many parties in this conflict have an interest in keeping up the charade. This includes both the former Ukrainian president Petro Poroshenko and Vladimir Putin, Russia's current president. Both have rejected any talk of changing the Minsk-2 agreement, as this would undermine their credibility. Yet neither is interested in taking formal responsibility for Donbas. [Petro] Poroshenko's legitimacy rested almost entirely on the fight against Russia, and he had no interest in letting Donbas vote in the presidential elections in 2019. The Kremlin does not want either to pay for Donbas or to limit its options in meddling in the rest of Ukraine. ${ }^{28}$

Besides, after Volodymyr Zelenskiy had taken the President's Office, there are big expectations of changes and conflict resolution.

Despite that, the documents were signed by all parties to the conflict with the initiative, assistance, and support of the OsCE. Important international policy actors, such as France and Germany (in Normandy format), have been involved in the development of Minsk Arrangements, which has greatly enhanced the authority and significance of these agreements and had certain influence on the effectiveness of decision implementation by Russia and Ukraine since their negotiations were conducted at the highest level with the

26 'овsıе: Obstrily zafiksovano u Debaltsevomu, Donetsku, Luhansku ta Raihorodtsi', UNI$A N, 2015$. Available at https://www.unian.ua/politics/1044376-obse-obstrili-zafiksovanou-debaltsevomu-donetsku-lugansku-ta-raygorodtsi.html (accessed 28 May 2019).

27 'Seizing the Moment: From Early Warning to Early Action', in Special Report No.2, International Crisis Group, 2016. Available at https://www.crisisgroup.org/global/seizing-moment -early-warning-early-action, 23 JUNE 2016 (accessed 22 June 2019).

28 'Ukraine and Russia are both trapped by the war in Donbas' in The Economist, May 25th 2017, Available at https:/www.economist.com/europe/2017/05/25/ukraine-and-russiaare-both-trapped-by-the-war-in-donbas (accessed 8 December 2019). 
participation of presidents of both States. In this way, we are not alone in our view that the international community is highly involved in resolving the conflict in Ukraine. However, if the situation in the field gets worse, it is the OSCE's mission to become the eyes and ears of the international community. ${ }^{29,30}$

It is known that the OSCE usually operates in the field. Thus, by the decision of the osce Permanent Council, the osce Special Monitoring Mission to Ukraine has been operating since March 21, 2014. It was sent to monitor and objectively report on the situation in the East of the country as well as to facilitate a dialogue between the parties to the conflict. The functioning of the mission has repeatedly been extended by the Permanent Council annually due to the ongoing military tension in the conflict zone.

It should be mentioned that the SMM had been designed and deployed before the conflict in the East escalated. Of course, there were attempts of proRussian protests to seize the Donetsk and Luhans'k Regional State Administration (RSA) buildings in the wake of the Ukrainian revolution 2014. However, pro-Russian protesters, who occupied the RSA from 1 March 1 to 6 March 2014, were removed by the Security Service of Ukraine (SBU). Unmarked separatist militants seized the Donetsk city office of the Internal Affairs Ministry on April 12 without any resistance. The anti-terrorist operation (АTO) started on 14 April 2014. That is why the situation had changed and the SMm's role evolved while its mandate was formally unchanged.

The key tasks of the observers are monitoring of ceasefire regime; monitoring and verifying the removal of heavy weapons to reduce tension and strengthen the conditions of peace, stability and security, and assisting in monitoring and supporting the implementation of OSCE principles and commitments. It is crucial to note that one of the main functions of the observers' mission is reducing information problems to decrease fear and mistrust, prevent accidents, etc. The monitoring also aims to ensure the reliability of the fulfilment of the obligations by the parties, especially in the process of disarmament and demobilization. ${ }^{31}$ The sMm's mandate is not limited to the Luhansk and

29 Walter Kemp, 'Osce Peace Operations: Soft Security in Hard Environments', International Peace Institute, 2016. Available at https://www.ipinst.org/wp-content/uploads/2016/o6/ 1606_OSCE-and-Peace-Operations.pdf (accessed 23 May 2019).

30 Arild Tjelle, 'Eyes and ears of the OsCE in volatile Eastern Ukraine', in UiO: Norwegian Centre for Human Rights, 2016. Available at http://jus.uio.no/smr/english/about/programmes/nordem/news/2015/smm-deployment.html (accessed 22 June 2019).

31 Nikolaus von Twickel, Gwendolyn Sasse and Mario Baumann, 'Russian Analytical Digest No. 214: The Armed Conflict in Eastern Ukraine', Center for Security Studies (css), 2018. Available at https://css.ethz.ch/en/services/digital-library/articles/article.html/7b91e171a779-43d3-9f24-35e8a88d8974/pdf (accessed 22 June 2019). 
Donetsk regions of Ukraine, enabling the mission to cooperate with public authorities of all levels, representatives of civil society, ethnic and religious (denominational) groups and local communities in order to maintain a dialogue and reduce social and political tensions in the state. ${ }^{32}$ According to the osCE Permanent Council decision, observers stay in the territories that are controlled (Kherson, Odessa, Lviv, Ivano-Frankivsk, Kharkiv, Dnipro, Chernivtsi) and uncontrolled by Kyiv (Donetsk, Luhansk). The work of the mission has been repeatedly expanded by the decisions of the Permanent Council due to constant tension and hostilities in the conflict zone, and the contingent of observers has also been increased. Initially, the mission consisted of 100 civilian observers; however, it has been expanded. ${ }^{33}$ Given the fact that all of the OSCE's decisions are taken by consensus of the 57 Permanent Council participating States and considering the original reluctance, Russia nevertheless, agreed to send the mission to Ukraine and even directed some observers there. ${ }^{34}$ As for 1 July 2019 , the mission consists of 762 observers from 44 participating States of the OSCE (the total number of mission members is 1,315). ${ }^{35}$ The vast majority of its employees are in particular districts of Luhansk and Donetsk regions. The largest number of observers are citizens of the US (57 persons), slightly fewer citizens of the United Kingdom (54 persons), Bosnia and Herzegovina (47 persons), and Bulgaria (42 persons). There are 37 persons from the Russian Federation. ${ }^{36}$

In general, the OSCE organisational structure can be assessed as optimal, since its mission was assigned with the beginning of the conflict, its work in the security dimension occurs in various directions. At the same time, Ukraine has taken advantage of the possibility that every country, which accepts the organisation's mission, can suggest, if necessary, increasing the number of observers. However, the difficulties in the organisation's activity (mainly consensus approach to making decisions) can automatically cause the mission to be curtailed.

32 'Special Monitoring Mission to Ukraine: The Facts', OsCE: Organization for Security and Co-operation in Europe, 2016. Available at http://www.osce.org/ukraine-smm/116879? download=true (accessed 22 June 2019).

33 'Survey of OSCE Field Operations', Secretariat of Conflict Prevention center, 2019. Available at http://www.osce.org/cpc/74783?download=true (accessed 22 June 2019).

34 Erwan Fouéré, 'Ukraine and Security Disorder in Europe - A Defining Moment for the OSCE?', Centre for European Policy Studies, 2014. Available at http://aei.pitt.edu/50745/1/ EF_OSCE_and_Ukraine.pdf (accessed 13 May 2019).

35 Report 1 July 2019, osCE Special Monitoring Mission to Ukraine (SMM), 2019. Available at https://www.osce.org/special-monitoring-mission-to-ukraine/424880?download=true (accessed 22 June 2019).

36 Ibidem. 
Representatives of the SMM reject accusations by pro-Russian supporters, which claim the SM M has taken a hard-line with regard to Russia, the LPR, and DPR. It insists on the objectivity of their work as well as on the fact that it is not the organisation, but the parties to the conflict that should agree and put an end to hostilities, and its observers should be invited to the line of delimitation solely to monitor the implementation of these arrangements. The activities of the OSCE missions, including the mission to Ukraine, are reflected in publications: daily, operational, thematic and weekly reports. ${ }^{37}$ The rhetoric in these reports is neutral, as observers capture only what they have seen with their own eyes or with the help of special devices. Therefore, the Mission's reports reflect what happened and where. The SMM can monitor the situation on both sides of the front line. At the same time, observers of the organisation often describe cases of shelling in a certain territory but never say that the shelling took place 'from the opposite side' and do not accuse of it any party. The mission reports, in which something can be brought to light, indicate the firing direction and the type of weapon used. Such an impartial approach causes dissatisfaction and criticism of the organisation from both parties to the conflict, especially in cases when the shelling caused a significant number of casualties.

Often, OSCE mission reports provide information on the current humanitarian situation in the conflict region. In addition, the reports often mention obstacles to the OSCE mission's access to the location of a shelling or other critical situation, which is also a violation of the Agreement. ${ }^{38}$ The SMM is the only international government organisation that monitors the conflict. In addition to reporting to both the parties to the conflict and the organisation's leaders, smm representatives regularly meet the civilians affected by the conflict in the region, organise roundtables with representatives of the authorities and the civil society, deliver humanitarian assistance, and provide repair groups access to the locations of industrial disasters along the front line. Thus, after the Malaysia Airlines plane crash in the Donetsk region, smm representatives were the first international observers to arrive at the location of the disaster. They also provided access to other international experts to the scene. ${ }^{39}$

37 'Reaktsiia овsie na kryzu v Ukraini i navkolonei', osCE: Organization for Security and Cooperation in Europe, 2015. Available at: http://www.osce.org/uk/home/125576?download= true (accessed 12 May 2019).

38 'Shchodenni i operatyvni zvity Spetsialnoi monitorynhovoi misii v Ukraini', osCE: Organization for Security and Co-operation in Europe, 2019. Available at: http://www .osce.org/uk/ukraine-smm/reports (accessed 22 June 2019).

'Reaktsiia o Bsie na kryzu v Ukraini i navkolo nei', osCE: Organization for Security and Cooperation in Europe, 2015. Available at: http://www.osce.org/uk/home/125576?download= true (accessed 12 May 2019). 
Using the methodology of swoт-analysis on the activities of the SMM, strengths, weaknesses, opportunities, and threats have been identified. In addition to providing analysis for the SMM specifically, these also shed light - in terms of strengths, weaknesses, opportunities, and threats - on the whole organisation.

\section{STRENGTHS}

- The flexibility of the mandate and adaptability of the Mission: An assessment of the conflict according to international norms and the use of all possible mechanisms for its regulation.

- The scope of the SMM's monitoring: The Mission monitors the situation of the entire territory of Ukraine. ${ }^{a}$

- The systematic collection and dissemination of information about the security situation: The Mission records violations of previous agreements by the parties, establishes responding facts to specific incidents in the conflict zone and reports on them.

- The decision-making process of the OSCE: Every participating State operates on an equal vote and every party has the right of veto. Decisions are made by consensus, encouraging participants to negotiate and compromise. There is a multidimensional approach to the crisis solution and the principle of consensus is used. A large number of OSCE participating States provide the highest level of international confidence and limit the ability of Russia to accuse the organisation of bias.

- The establishment of the mission's contacts with representatives of conflicting parties and the ability to set up a dialogue to facilitate the normalization of the situation in the field and reduce tension.

- The setup and implementation of joint projects in Ukraine to ensure democratization and proper governance, the rule of law and human rights in the military and political sphere, etc. and in general promoting the implementation of reforms in Ukraine.

- The monitoring of human rights and freedom of mass media in Ukraine and observing the course of the election in Ukraine, which increases its external legitimacy.

- The search for diplomatic means to overcome Ukraine crisis within the Minsk Agreements and for wider solutions - the answers to the challenges of European security - from terrorism to natural disasters. 


\section{WEAKNESSES}

- The crisis of trust in the organisation and the lack of political will of its leaders and members which affect the trust in SMM to Ukraine. ${ }^{\text {b }}$

- The absence of dialogue within the organisation: This is primarily due to external influence and common doubts about the objectivity of the SMM, as a result of the fact that the mission does not operate in the occupied Crimea, thereby confirming and acknowledging Russia's expansionist actions.

- The complexity of the decision-making process, which implies the participating countries to reach a consensus. This leads to the lowest common denominator situations and deadlocks. The risk lies in the possibility of Russia to influence any the OSCE decision, including the work of the SMM. The lack of a mechanism of coercion in implementing agreements, which leads to violations of agreements.

- The inevitable perceptions by the Ukrainian side of bias due to Russian monitors' presence in the Mission. ${ }^{\mathrm{c}}$

- The inability of the SMM's mandate to monitor the situation on the entire territory of Ukraine and to allocate the resources. The Mission focuses on the East of Ukraine, resulting in resources being diverted there to monitor the ceasefire, thereby making monitoring in other regions more difficult.

- The weak operational possibilities of the Mission including the inability to react and defend oneself by using weaponry. There are restricted opportunities for physical manoeuvring across the territory. ${ }^{\mathrm{d}}$

- The peculiarities in the work of unarmed observers including their inability to patrol at night when the greatest number of violations occurs. Undoubtedly, such measures are taken for the sake of security, but at the same time, they jeopardize the objectivity of the information provided.

\section{OPPORTUNITIES}

- The possibility of OSCE missions being equipped with new security tools to eliminate the risks for international observers and to better monitor in the conflict zone.

- The possibility of the development of a political dialogue and co-operation in the security sphere in all its dimensions, including through the inclusion of the OSCE in negotiations in Normandy format. ${ }^{\mathrm{e}}$

- The possibility of counterbalancing the SмM by including Ukrainian members in the Mission's activities, thus, engaging Ukraine in the monitoring process. 
- The protection of the database as an important component of the OSCE and smm effective activity.

- The possible resumption of activities of international humanitarian organisations with the support of the SMM in the part of Donbas controlled by the Russian Federation.

- The OSCE's monitoring of the snap elections, which was exclusively based on the legislation of Ukraine and OSCE standards.

- The increasing of the OSCE's authority to maintain international peace. Strengthening the OSCE's potential as an instrument for early warning of the conflict, its prevention, management of crisis and conflict situations and the post-conflict reconstruction. Researchers claim that despite the criticism of key standards of the OSCE, the Russian-Ukrainian war has revitalized the organisation and highlighted its potential for crisis prevention and peaceful conflict resolution.

- The possibility to enhance the organisation's co-operation in the spheres of law, education, defence, human rights, the environment, minorities, the fight against organised crime, terrorism and human trafficking, the promotion of tolerance and non-discrimination, the assertion of freedom of speech, etc. Ensuring the de facto observance of fundamental principles of the 1975 Helsinki Final Act by the Russian Federation and its commitments within the OSCE, violated because of the military intervention in Eastern Ukraine, the occupation and annexation of the Autonomous Republic of Crimea and the city of Sevastopol, kidnapping and retention and also the internment of Ukrainian citizens (military and civilian) in Russia.

- The possibility to search for models of peaceful resolution of post-Soviet conflicts which directly or indirectly involves the Russian Federation. Development and implementation of more effective mechanisms of arms control verification (at operational and mission levels) that will, if necessary, have a rigorous impact on the offender, including applying legal sanctions (at the osce level).

- The possibility to resolve the complexity of the decision-making process by applying the mechanism "consensus-1" (the Moscow mechanism) though it is rarely used. ${ }^{\mathrm{f}}$

\section{THREATS}

- The reduction of the security level of the SMM observers because of violations of the Minsk Agreements and international legal acts that regulate and determine the status of the observers. 
- The fact that the SMM consists of unarmed civilian monitors, whose only defence tools are armoured vehicles and personal protection equipment. ${ }^{g}$

- The potential shutdown of the SMm's activity could deprive Ukraine of the opportunity to objectively inform the international community about the situation in the conflict zone and the state of affairs in the country. There is also a strong fear in Ukraine of being abandoned by the West allies.

- The freezing of the conflict in Eastern Ukraine and halting of the SMM's activity for status quo maintenance. ${ }^{\text {h }}$

- The accusations of co-operation of some OSCE members with militants of unrecognized DPR and LPR. This undermines the legitimacy of the mission in the eyes of most Ukrainians. There are numerous cases of photo-captures of professional soldiers, heavy weaponry, the downright activity of Russian Special Forces and their influence on the SMM's activity.

- The threat of cyber-attacks on the key bodies of the OSCE by different groups of hackers, especially from Russia.

- The possibility of the dissolution of the OSCE as an organisation that discredited itself during its Mission to Ukraine.

- The temporary suspension of the OSCE's support for the implementation of reforms in Ukraine.

aThere are a great number of observers in the Joint Forces Operation zone ( 762 persons) and at the checkpoints in the area of the Ukrainian-Russian border that is not controlled by Ukraine. According to the decision of the Permanent Council, observers have been placed in Kyiv, Kherson, Odesa, Lviv, Ivano-Frankivsk, Kharkiv, Donetsk, Dnipro, Chernivtsi, and Luhansk. However, the vast amount of observers is concentrated in Luhansk and Donetsk regions. Despite complex security conditions, the SMM conducts up to 45 daily patrols in Eastern Ukraine and 20 patrols in other places in Ukraine.

bDennis Sammut and Joseph D'Urso (2015) claim that the dilemma of the OsCE is clear: it needs Russia's agreement for the Mission to exist and Russian cooperation for the mission to operate, yet if it allows Russia to compromise the Mission, the whole credibility of the OSCE in future peacekeeping and monitoring operations will be compromised.

cIt is important to emphasize that Russia supports the separatists, hence, it is unacceptable for its observers to participate in the mission (there are 37 monitors from the Russian Federation). Analysts argue that the presence of Russians in the SMM is perceived as an anachronism, especially when Ukrainian observers are not included to the mission. The allegations of collusion between Russian members of the SMM and Russian separatists in Eastern Ukraine are often based on unofficial data. However, the analysts refer to the instances when such contacts between Russian members of the SMM and Russian separatists have been proven. In September 2014, it was proven that two persons, most likely separatists, had entered the OSCE car in Donetsk. Subsequently, the OSCE expressed its regret for the incident and promised to prevent recurrences. 
dFor example, the analysts refer to the General Wesley Clark speech in which he states that OSCE drones have been jammed and shot at by separatist forces, using technology the US forces have not faced in the wars in the Middle East. This exemplifies the limited extent to which unarmed OSCE monitors can operate in a conflict between two 21st century armies. eDennis Sammut and Joseph D'Urso note that there is a strong argument for why the OSCE Chairman-in-Office should have been included in Normandy Format, spearheaded by the presidents of France and Germany, including in the negotiations of Minsk II.

fTheoretically, this mechanism, adopted at the Prague osCE Council of Ministers meeting in 1992 and applied only once to the former Yugoslavia, could well eliminate Russia, as an aggressor state, from osCE activity in Ukraine and conflict resolution. Such a decision is possible, but unlikely given Russia's influence, the principle of consensus in the OSCE and, in general, the political and diplomatic situation on Russia's aggression against Ukraine. gNevertheless, it should be pointed out death of one SMM monitor in April 2017 (U.s. citizen Joseph Stone), and injuring of another two participants (a German woman and a Czech man). It was the first death to occur during an OSCE mission in many years, which has provoked strong shockwaves through the organisation. On April 23, 2019, Head of the osce Special Monitoring Mission to Ukraine (SMM) Ertuğrul Apakan paid tribute to SMM medic Joseph Stone, who was tragically killed and said that only then when people in eastern Ukraine are free of this scourge will there be a fitting and lasting legacy for Joseph Stone and all the other innocent victims.

hDennis Sammut and Joseph D'Urso note the need to recognize the risk that the SMM will become a guarantor of an unacceptable status quo.

Therefore, the following features of the OsCE Mission to Ukraine can be noted. In particular, the organisation's approach to managing the crisis in Eastern Ukraine includes the activities to monitor the conflict, to establish a dialogue and, to develop democracy. The wide range of issues the organidation is responsible for brings its multidimensional approach to crisis resolution. This should include the work of the organisation's staff with the public, training, communication with local authorities, organising negotiations, etc. At the same time, the following factors often hindered the Mission's ability to monitor the conflict: obstruction of access to places of military incidents; inadequacy of the Mission's equipment to the conditions in a combat zone; insufficient number of observers or their absence in places of possible escalation.

\section{Conclusions: Discussions about the Future}

In sum, the consensus view seems to be that the efficiency of the oscE's work in resolving conflict in Ukraine is generally controversial. The analysis of legal documents, specific institutional and operational activities of the osCE in Ukraine indicates positive and negative aspects which characterise the OSCE's activities. In spite of the difficult situation in Eastern Ukraine and the ambiguous position of the OsCE regarding war, according to Ihor Prokopchuk, Permanent Representative of Ukraine to the international organisations in Vienna, today's the osCE is the most effective platform for a weekly discussion 
of the Ukrainian crisis. No other international forum, including the UN, can give Ukraine such an opportunity to declare its position on the conflict both generally and in particular concerning the Russian Federation, so-called DPR and LPR. ${ }^{40}$

All things considered, Ukraine's position on the OSCE SMM correlates with analysts' suggestions on the future of the organisation. Research has found that there are three possible strategies for the development of the organisation. Firstly, the OSCE has to strengthen its current status as a guardian of common principles of the international order and an inclusive platform for political negotiations and crisis management (status strategy). Secondly, the organisation's work should focus on well-defined functions and activities based on strategic needs that emerge with respect to the maintenance of peace and international stability (niche strategy). Thirdly, the OSCE should aim for refining its role through the division of labour and coordination with other appropriate multilateral participants, mainly the UN, NATO and the EU (added value strategy). ${ }^{41}$

Taking everything into consideration, the OSCE is the main institution oriented on resolving conflicts in the European region. In the case of Ukraine, it is the only international governmental organisation that provides all members with information on compliance with the agreement by the parties. One of the advantages of the OSCE mission is its neutral status in the system of international organisations related to security measures. This position allows the involvement of a large number of participants in the negotiations. In the case of Ukraine, the OSCE has become a platform for negotiating with Russia as one of the parties to the conflict and without the consent of which it is impossible to resolve this international crisis.

Furthermore, the other achievement of the organisation was the involvement of both parties to the conflict to negotiate and reduce the intensity of hostilities. The OSCE's activities follow a multifunctional approach in resolving community crises, which includes a humanitarian aspect to work with the public and monitoring human rights. Observers try to be objective in their reports and describe only events they saw with their own eyes.

$40 \quad$ Hanna Shelest, 'овsıe: rik pidznakom Ukrainy', in Dzerkalo tyzhnia, 2014. Available at http://gazeta.dt.ua/international/obsye-rik-pid-znakom-ukrayini-_.html (accessed 22 June 2019).

41 Teija Tiilikainen (eds.), Reviving Co-operative Security in Europe through the oscE. Contribution of the OSCE Network of Think Tanks and Academic Institutions to the Panel of Eminent Persons, 2015. Available at https://www.osce.org/networks/188176?download=true (accessed 12 May 2019). 
Among the challenges of the OSCE activities that have a negative impact on the work of the SMM, we can consider the difficult decision-making process in the organisation, in accordance with the 'one state, one vote' policy and coordination of projects by consensus (unanimously). Another problem of organisation is the lack of a mechanism of coercion made within its agreements, which causes violations of these agreements and contributes to the unresolved Russian-Ukrainian conflict and other conflicts. The OSCE missions, particularly in Eastern Ukraine, are often criticized for not being present at the site of armed incidents. Unarmed SMM, observers as well as the inability to patrol at night when the violations occur most, are the reason for this. Of course, such measures have been taken for the sake of the safety of the organisation's staff, but at the same time, they jeopardise the objectivity and promptness of the information provided.

As a result, we can suggest the following recommendations to strengthen the OSCE's authority in resolving conflicts. Firstly, the organisation should reform its decision-making mechanism, especially when the parties to the conflict are involved in the process. In such cases, the application of the principle of absolute consensus is impossible, since the party to the conflict puts its (hostile) interests first towards other countries (objects of aggression) ignoring international principles and obligations, including those of the organisation. Secondly, within the OSCE, it is important to introduce a coercive mechanism (whether economic or political) for parties to the conflict in order to implement agreements. Thirdly, the OSCE missions should be equipped with the latest equipment and security tools to eliminate the risks for organisation's personnel and to improve monitoring of the situation in the conflict zone by international observers.

The activity of the organisation has a strong stabilizing effect on the conflict and it is an important source of monitoring and providing the information from conflict zones, in particular from the territory of military action in the Donbas. Today, it is the only international organisation that can inform the international community about the events in the East of Ukraine. In addition, most of all, Ukraine is interested in the unimpeded continuation of SMM activities and the geographical extension of its access, in particular, to the territory of the Crimea.

The unarmed, civilian OSCE mission, with more than 700 international observers, seeks to reduce tensions and report on the situation on the ground in Ukraine. At the same time, it is a conflict where extremely heavy weaponry is used, and the OSCE mission cannot withstand heavy artillery or anti-tank mines. The situation can change due to the implementation of the UN peacekeeping mission aimed at resolving the conflict as well as protecting the OSCE 
monitors; however, there is no hope for such a scenario to materialize. The Ukrainian authorities, seeking options for engaging international peacekeepers, put forward a proposal for sending the OSCE police mission to the conflict zone. However, the OSCE has no experience with such type of police mission. All the OSCE police-related missions were post-conflict missions and were limited to training of the local police forces.

Consequently, an analysis of the OSCE's work in resolving conflicts has shown that the organisation promptly responds to the emergence of conflicts and uses already developed methods for their solution. Despite that, the Russian-Ukrainian war is still the biggest political and operational challenge for the organisation, gradually turning into another 'protracted' conflict in the OSCE's area of responsibility that cannot be resolved by this structure. ${ }^{42}$ It means that the OSCE, which orients on consensus in the decision-making process, will need the political will of all 57 Member States, which, in the light of decades of Russia's rejection of Euro-Atlantic security architecture, cannot be achieved overnight. ${ }^{43}$ The activity of the OSCE SMM to Ukraine confirms the necessity to reform the structure and mechanisms of the organisation for preventing and resolving long-lasting conflicts. Such reform is especially necessary and urgent in the light of the resolution of the Ukrainian conflict and the effective resolution and prevention of upcoming regional and international crises.

\section{Biographies}

Lesia Dorosh is Associate Professor of the Department of Political Science and International Relations of Lviv Polytechnic National University (Ukraine) and has an academic degree of $\mathrm{PhD}$ in Political Science. The area of her scientific research: political theory and theory of international relations (in particular the foreign policy of Ukraine, aspects of international, European and Ukrainian security in modern world), issues of current state building of Ukraine. She has developed the courses: "International and European Security", "Theory of

42 Christian Nünlist, 'Reviving Dialogue and Trust in the OSCE in 2018', in Center for Security Studies (css), 2017a. Available at https://css.ethz.ch/en/services/digital-library/articles/ article.html/5dıbd2ac-1928-4942-93e6-cdocd044662f/pdf, 15 Jan 2018 (accessed 22 June 2019).

43 Christian Nünlist,'The OSCE and the Future of European Security', in Center for Security Studies (css), 2017b. Available at https://css.ethz.ch/content/dam/ethz/special-interest/ gess/cis/center-for-securities-studies/pdfs/CSSAnalyse202-EN.pdf (accessed 22 June 2019). 
International Relations", "Foreign Policy of Ukraine", and "Fundamentals of Geopolitics and Geostrategy". She also published more than 30 scientific articles in political science and international relations in Ukrainian and foreign reviews.

Olga Ivasechko is Associate Professor of the Department of Political Science and International Relations of Lviv Polytechnic National University. In 2012, she defended her PhD thesis in Political Science. The area of her research: history of political thought, the European Union Studies, issues of regional politics and integration, and social aspects of politics. She has developed the courses "Energy Security", "The European Union in International Relations", and "Regional Politics and Integration". 